\title{
Opinion \\ Dark Clouds over the Silk Road: Challenges Facing Mountain Environments in Central Asia
}

\author{
Roy C. Sidle ${ }^{1,2,3}$ (D) \\ 1 Mountain Societies Research Institute, University of Central Asia, Khorog GBAO 736000, Tajikistan; \\ roy.sidle@ucentralasia.org \\ 2 Institute of Global Innovation Research, Tokyo University of Agriculture \& Technology, \\ Fuchu, Tokyo 183-8538, Japan \\ 3 Sustainability Research Centre, University of the Sunshine Coast, Sippy Downs, Queensland 4556, Australia
}

Received: 24 September 2020; Accepted: 7 November 2020; Published: 13 November 2020

check for updates

\begin{abstract}
Central Asia is a vital link in the huge Chinese Belt and Road Initiative (BRI) that follows much of the ancient Silk Road routes in this region. Other than the economic expansion and trade benefits associated with this complex infrastructure system, little is known about the many of the exogenous issues and direct environmental and socioeconomic impacts surrounding the BRI in Central Asia. This opinion paper takes a sharper look at some of these externalities and potential effects through a sustainability lens. Major environmental concerns focus on the proliferation of spur roads that will develop off upgraded or new Belt Roads to promote exploitation of natural resources. Steep, high-elevation landscapes in the Pamirs and Tien Shan pose problems for road location and construction, and the history of road building in less formidable terrain in Yunnan, China is unsustainable, leading to epic landslide and gully erosion, which degrade river systems. Furthermore, many socioeconomic issues may arise like debt dependencies of poor countries, spread of communicable diseases into remote communities, depletion of mineral resources, and implicit compliance with pro-China policies. While some of the poorer post-Soviet nations can reap short-term benefits from BRI plans, it is urged that they assess the long-term sustainability of BRI development and play an active role in determining the conditions for implementation.
\end{abstract}

Keywords: Belt and Road Initiative; sustainable road development; mountain roads; natural hazards; sediment disasters; natural resource conservation; communicable disease spread; remote mountain communities; Central Asia

\section{Historical Background}

Common perceptions of the Silk Road evoke nostalgic images of caravans transporting silk, spices, precious gems, and other trade items from China to the Roman and Persian Empires beginning in the 1st Century BC. Recent studies have noted that Central Asia played a more significant role than previously thought in the development of earlier Silk Road routes due to the interactions among nomadic pastoralists, early political structures in the Tarim Basin, and the Han Dynasty [1,2]. Many of the routes of the early nomadic herders in high elevation pastures of what is now Central Asia match closely to those of the Silk Road traders ${ }^{2}$ (Figure 1). The travels and chronicles of Marco Polo along the northern portions of the Silk Road in the late 13th Century represent some of the first European scholarly accounts of the region. A very dark impact emerged during the mid-14th Century when the Black Death plague, caused by rodents hosting the deadly bacterium Yersinia pestis, spread from near or within China through the Caucasus into Europe ${ }^{3}$. Evidence of this spread has been uncovered along the ancient Silk Road routes with the overall impacts resulting in the deaths of at least 30 million people, including about $30-50 \%$ of the European population in a 5-yr period [3,4]. During much of the 
Renaissance, the Central Asian region had profound influence on the exchange of scientific, medical, agricultural, and cultural information to both the east and west, facilitated by the Silk Road system [5]. In the mid-15th Century, the Ottoman Empire boycotted trade with the west, closing Silk Road routes and prompting European traders to navigate by sea to the east during the Age of Discovery. By the 19th Century, the traditional use of these trading corridors changed, and a new breed of explorers from Europe, Japan, and Russia began to travel and study within the Silk Road region.

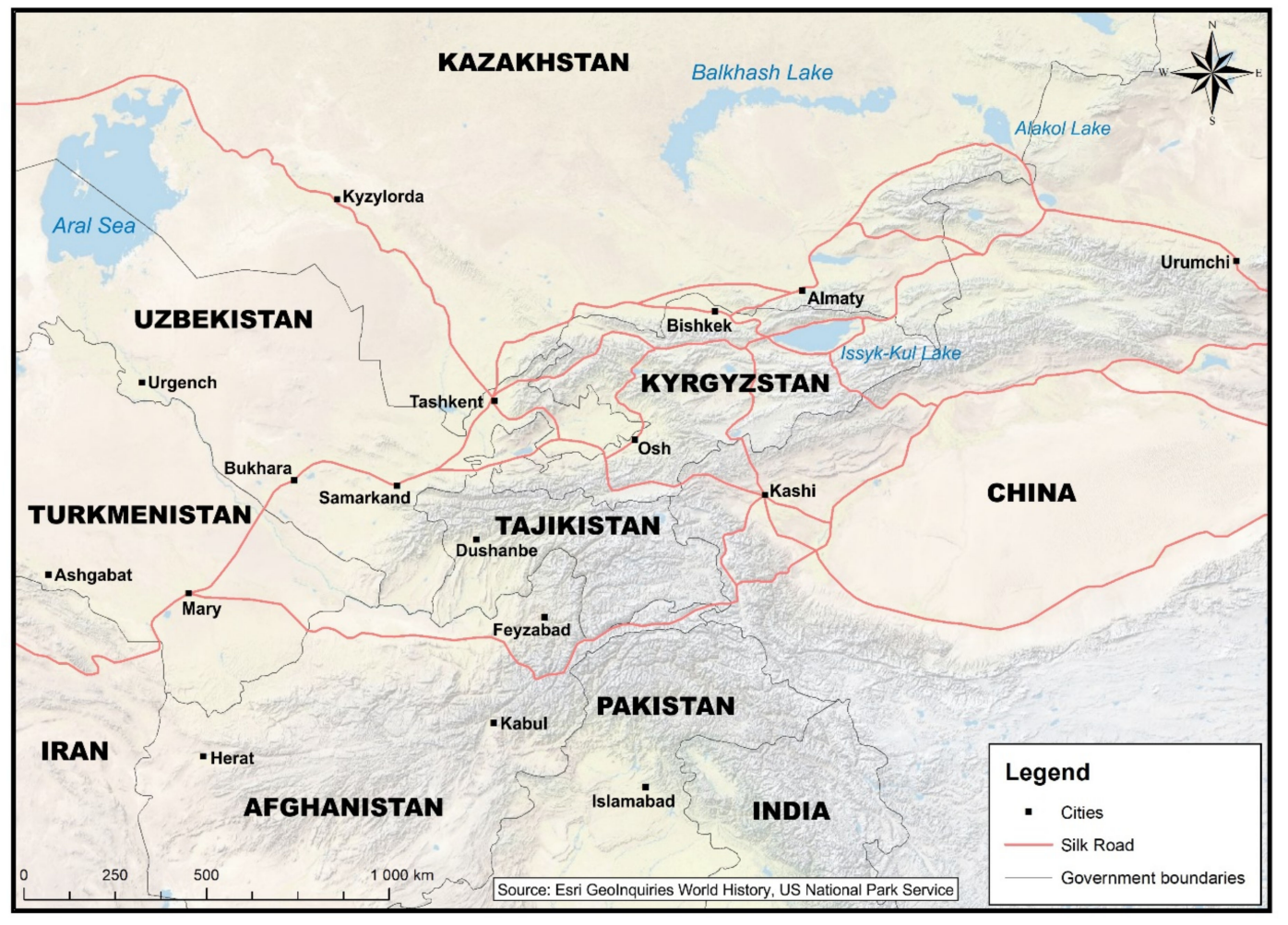

Figure 1. Map of the ancient Silk Road routes through the greater Central Asia region with countries shown in their current jurisdictions.

In September 2013, Chinese President Xi Jinping first introduced the Belt and Road concept at a speech given at Nazarbayev University in Kazakhstan, underscoring the strategic importance of Central Asia as a link to revive and expand trade along the ancient Silk Road system [6,7]. A summary of different perspectives on China's motivation for this potentially $\$ 4$ trillion (USD) investment, mostly focuses on economic expansion and trade; energy security (including access to natural resources); social stability and security; and international political influence [8]. Furthermore, China views the development of these corridors through Central Asia as a promising solution to the persistent instability in Xinjiang Province where the oppressed Uyghur minorities reside [9]. In light of these unstable conditions adjacent to Tajikistan, Kyrgyzstan, and the Wakhan corridor of Afghanistan, it is relevant to note that in addition to the recent Chinse crackdown on Uyghur Muslims in Xinjiang, which prompted a formal expression of concern by the United Nations Committee on Elimination of Racial Discrimination in August 2018 and several legislative hearings in the United States, there is a contemporary history of repression and violence dating back to 1931 [10,11].

\section{Problems with Mountain Roads in the Region}

Despite the past and ongoing economic and social issues, little attention has been given to how the expansion of this road system, as well as the spur roads that would eventually develop, will impact the environment and the health of indigenous people in the mountains of Central Asia. The Belt and Road Initiative (BRI) encompasses an expansive transportation network in which Central Asia provides 
the critical link between China and Europe, Africa, East Asia, Russia, and the Middle East. Overall, the BRI reaches across 65 countries; however, the challenges and impacts within mountainous Central Asia are some of the greatest [6-8].

The construction of mountain roads in developing Asian nations has been a mixed blessing. Contemporary mountain roads in the greater Central Asia region have typically been poorly planned and developed due to formidable terrain, sparse populations, and poor governmental budgets for road development. This is particularly true in the Tien Shen and Pamirs, which cross much of Kyrgyzstan, Tajikistan, and northern Afghanistan where the terrain is extremely steep and many local transport corridors consist of unpaved roads, footpaths, animal tracks, and motor bike trails. These small corridors link people to neighboring communities, markets, and larger road systems, as well as support the development of local agriculture, grazing, mining, trade, and border security (Figure 2).

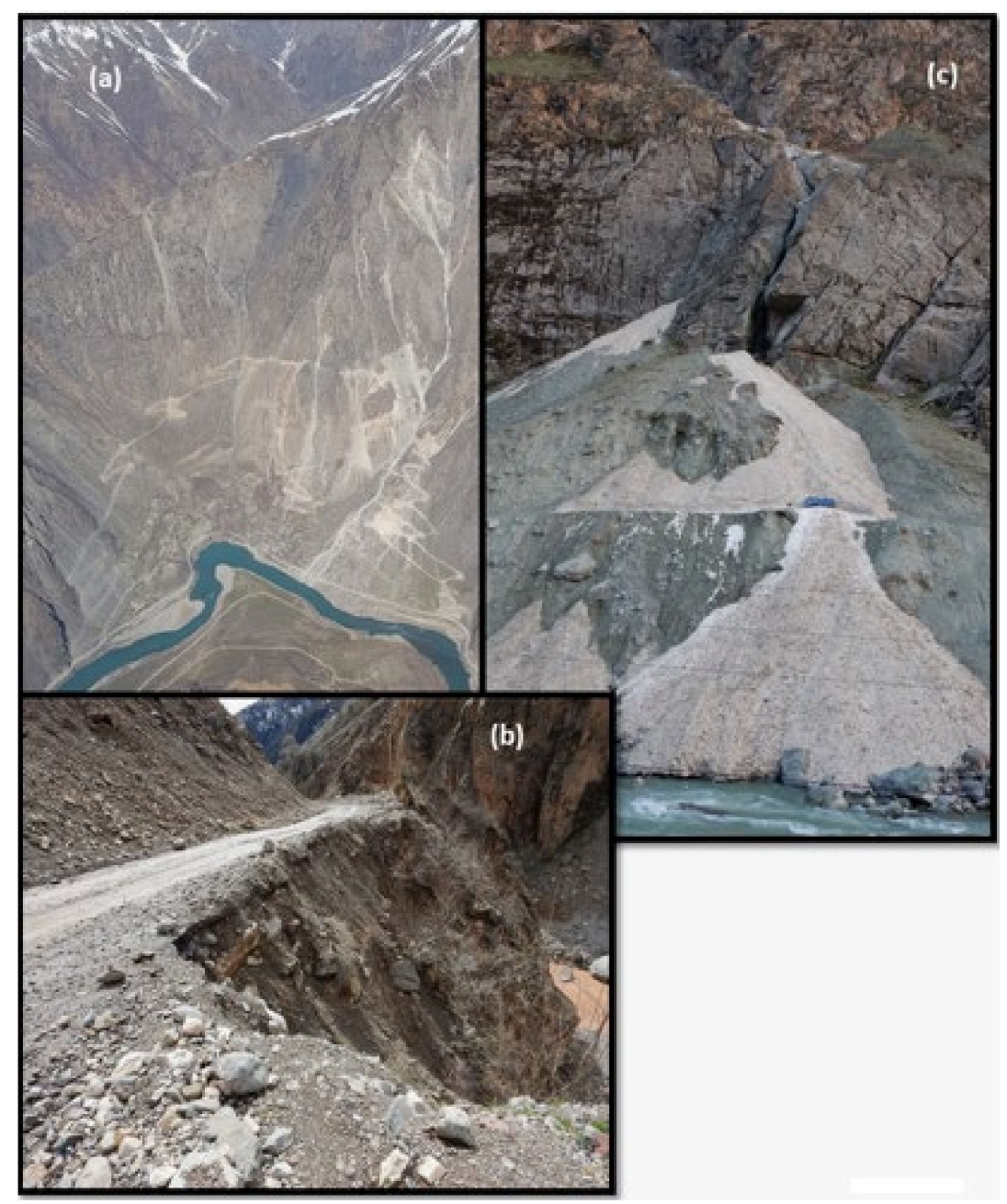

Figure 2. (a) Steep mountain roads into mining areas and pastures in the Tajik Pamirs. (b) Road connecting villages in the Pamir-Alay Range; and (c) Border road along the Afghan side of the Panj River; note extensive rockfall and blue track clearing the snow avalanche.

Much of the planned BRI development in Central Asia coincides with locations of the ancient Silk Road (Figure 1). The economic focus of this mega-project has largely excluded environmental provisions such as Environmental Impact Assessments (EIA's) and “environmental Regional Trade Agreements" [6,12-16]. While EIA's have been effectively employed in many development projects worldwide, the vast scope and international nature of the BRI makes implementation of EIA's difficult even under ideal circumstances where all parties theoretically support sustainable development. 
In this case, where a wealthy nation can exert undue pressure on poor nations (Tajikistan, Afghanistan, and Kyrgyzstan) the implementation of EIA's is elusive at best and to date has been haphazard or nonexistent [13]. Many Chinese policies related to overseas environmental protection are non-binding and Chinese standards for "green" project development may not be considered "green" by international standards [15]. Given the complex environmental and social impacts of mountain roads, detailed assessments are needed to ensure protection of travelers, property, indigenous communities, and the natural environment [17]. These assessments need to be holistic and capture wide scale environmental and social issues associated with road development [15], but also need to address smaller-scale environmental problems that affect local mountain communities and travelers.

Most of the initial BRI investments by China in Central Asia have been in the wealthier nations-e.g., the $2233 \mathrm{~km}$ Western Europe-Western China Highway that runs through Kazakhstan [15]. A relatively new initiative, the China-Central Asia-West Asia Economic Corridor, designed to link China to the Arabian Peninsula, has plans for routes crossing Kyrgyzstan and Tajikistan but, at present, most attention has focused on the northern route through the Chinese-Kazakhstan frontier [18]. Tajikistan is also developing some internal rail and roads routes with Chinese support, but cross-border routes have yet to be developed [18]. New routes through Afghanistan appear to be the most challenging in the region.

The poorer Central Asia nations, Tajikistan, Kyrgyzstan, and, more recently, Afghanistan, play pivotal roles for BRI development due to their locations at the intersection of the Pamir, Karakoram, Hindu Kush, and Tien Shan mountain ranges. This formidable terrain necessitates careful planning and construction of roads. While some sectors of these countries may benefit economically from new infrastructure developments primarily due to lower shipping costs [19], issues here and elsewhere have been raised about the lack of local employment opportunities, forfeiture of mining and land rights, disruption of traditional land management practices, and extensive creation of debt from loans $[20,21]$. In 2017, the Asian Infrastructure Investment Bank (a development bank initiated by China) granted a $\$ 60$ million USD loan to Tajikistan for rehabilitation of the Nurek Dam and hydropower station. Chinese researchers have suggested that closer ties with the BRI will help solve financial issues related to large hydropower projects, such as the Rogun hydropower project, located about $70 \mathrm{~km}$ upstream of Nurek Dam on a tributary of the Vahksh River in Tajikistan [22]. While the economic virtues of the BRI are also being promoted via Central Asian students studying in China [23], such benefits appear short-term, unsustainable, and ignore many social and environmental externalities $[6-8,14,20]$.

Less discussed in the media and research dialogs are certain environmental and health issues associated with the future expansion of this mountain road network. While some studies have linked BRI development to environmental degradation, these analyses have focused largely on air quality, habitat and biodiversity loss, and local pollution effects $[6,13,14,24]$. Few reports have focused on the problems of road building or expansion in steep terrain. As such, issues that have received less attention, and which will be much more significant for sparsely populated, mountainous Central Asia, include impacts of natural hazards on mountain roads and travelers; sediment disasters along roads affecting indigenous communities and water resources; and potential health effects and social injustices associated with exogenous economic expansion and use of roads in transborder areas.

\section{Socioeconomic Issues}

The combined effects of the collapse of the Soviet Union and the economic crisis in Russia in the early 1990's provided a segue for China to tap into the natural resources and commodities of the newly emerging Central Asian nations and secure borders [25]. Because government structures and thus political ramifications vary from country to country in Central Asia, it is difficult to completely view the potential impacts of the BRI as a monolith in this region. However, since most of these countries embraced China's trade and investment overtures, it appears that the major differences amongst these nations lie in the types of terrain where new infrastructure will constructed or where old roads will be 'upgraded'. Given the focus here on the poorest mountainous regions of greater 
Central Asia, particularly the Pamirs, Tien Shan, and the intervening Pamir-Alay range, many of the economic targets that China is capitalizing on are similar. For example, Kyrgyzstan serves as a transit hub and has received Chinese investments for infrastructure development and extraction of natural resources, particularly gold mining [7]. Tajikistan now relies heavily on inexpensive goods from China as well as Chinese investments in infrastructure, hydropower, cement production, and mining, while Afghanistan is targeted for copper mining and oil exploration [7,25]. All of these road networks are targeted for future expansion under the BRI.

Despite China's exultations of economic and welfare benefits associated with the BRI, these achievements have been poorly documented. Recent evidence from initial BRI investments in Kyrgyzstan have shown little net economic gain [26]. Given China's history of natural resource exploitation in Central Asia, clearly opening of new spur roads will expand development and resource extraction whilst linking remote villages to social services and economic outlets. In the past decade, China has overwhelmed these poor nations with cheap merchandise and extracted precious minerals and petrochemicals while providing few local jobs, and even requiring loyalty from loan recipients to the One China policy, including not criticizing policies and treatment of Uyghurs and Tibetans [27].

Road system expansion in other similar areas has been linked to transformations of traditional cultivation practices in rural uplands [21] and implicated in deforestation and land exploitation in remote regions [28]. Furthermore, increased development activities in remote mountain villages expose isolated residents to communicable diseases, as evidenced by the current COVID-19 pandemic. Vector-based disease transmission is complicated, but transportation corridors can facilitate the spread of disease [29]. For example, the undeveloped mineral wealth in Tajikistan has been recently attracting major attention from China [30]. Such resource exploitation offers little sustainable benefits to the country and will expose isolated locals to outside diseases. Since the 1990's exports from Uyghur forced-labor camps in the Xinjiang region, particularly via the 'cotton supply chain' [31] have been pouring into and transiting through Central Asia, constituting another potential disease vector, not to mention human rights abuses. Another often overlooked development is the expansion of military exercises that China is conducting in Central Asia-the most of anywhere in the world [25]. Along the poorly maintained Pamir Highway (M51), which connects into western China, large trucks hauling Chinese goods are increasingly pouring through Tajikistan deteriorating and often blocking the road and causing noise and dust pollution in Pamir communities. Implementation and expansion activities associated with the BRI will add new pressures to most of these existing problems.

\section{Escalation of Natural Hazard Impacts}

The mixed blessing of the BRI is confounded by a host of environmental issues, particularly the history of poorly located and constructed roads creating hazards for travelers, such as rockfall, landslides, debris flows, and snow avalanches, as well as prolonged road closures. The BRI will exacerbate hazards in Central Asia, particularly when spur roads are constructed in steep terrain for extraction of natural resources. A newly widened and developed road on the Afghanistan side of the Panj River is already experiencing landslides, rockfalls, debris flows, and snow avalanches, periodically blocking the road, impacting travelers, and risking obliteration of this border road with Tajikistan (Figure 2c).

Mountain roads cut into steep terrain decrease the stability of hillsides by: (1) undercutting steep slopes, thus removing support; (2) overloading the downslope side of the road with unstable fill or excavated materials; (3) oversteepening both the cut and fill slopes; and (4) concentrating road runoff onto unstable sites below the road [32]. As such, poorly located and constructed mountain roads abound in the Pamirs, Pamir-Alay Range, and Tien Shen where they significantly increase the incidence of landslides and debris flows, which damage the road, impact downslope property and communities, and export excess sediments to receiving streams [33].

While virtually no research has documented the extent of landslides, debris flows, and rockfall associated with mountain roads in Central Asia, studies in East Asia (including China) reveal an 
ongoing legacy of these hazards causing catastrophic sediment loads in rivers and significant property damage and deaths [33]. Landslide erosion along newly developed or expanded mountain roads within UNESCO's designated "Three Parallel Rivers of Yunnan Protected Areas" is the highest ever reported worldwide, ranging from about 1000 to more than $48,000 \mathrm{Mg} \mathrm{ha}^{-1} \mathrm{yr}^{-1}$ within the road footprint, causing extensive sedimentation in tributaries and the main stems of the Salween, Mekong, and Yangtze Rivers, not to mention degraded aquatic habitat and water quality transmitted to poorer downstream nations [34,35]. To put this into perspective, the highest measured road-related landslide rate in the Salween River basin of Yunnan, China was more than 800 times higher than landslide rates along logging roads in unstable terrain of the Pacific Northwest, USA, in the early 1980's that led to stoppage of timber harvesting on Federal lands. These mountain roads in Yunnan are in similar geomorphic settings as many of the secondary roads in the Pamirs and Tien Shan. Such a management legacy within China does not bode well for its development and expansion of mountain roads in poor regions of Central Asia.

Naturally occurring landslides, debris flows, and rockfall in steep terrain also damage mountain roads. At high elevations, progressive permafrost melting poses problems for road construction, including initiation of mass failures, particularly in a warming climate [36]. Runoff from road surfaces 'short-circuits' rainwater and snowmelt to streams, enhancing floods, triggering debris flows, and causing channel headcutting and gully initiation downslope of the road depending on the connectivity of the road system $[37,38]$ (Figure 3a). Snow avalanches block roads and frequently injure or kill travelers and workers (Figures 2c and 3b) [39]. Rockfall is exacerbated by cutting roads through mountainous terrain, particularly where bedrock is naturally fractured and dipping into the road cut (Figure 3c). And these hazards are not confined to roads cut into hillsides. Valley bottom roads in the Pamirs and Tien Shan often cross large debris fans, which experience periodic avulsions that can obliterate large segments of road networks (Figure 3d). All these hazards are evident now but will increase with expansion of the BRI.

To illustrate the significant interactions between mountain roads in the Pamirs and mass wasting events (landslides, debris flows, and rockfall), major geohazard features along a $42.5 \mathrm{~km}$ segment of the M41 highway following the Gunt River from just east of Khorog, Tajikistan to just west of Vodzh were assessed both in the field and via Google Earth Pro. There were 13 landslides $\geq 2.5$ ha in area along this segment that were either affected by the road or impacted the road, including a few in proximate side roads. Mean landslide area was $10.4 \mathrm{ha}$, and areas ranged from 2.5 to $17.6 \mathrm{ha}$. Numerous smaller landslides and rock failures also occurred. Many more landslides were caused by spur roads that traversed from the valley floor onto the hillslopes. There were also nine major debris fans that were either crossed or proximate to this road segment, most of which were colluvial fans formed by debris flows. Three of the fans exhibited characteristics of alluvial fans, although evidence from the contributing mountain stream suggests that at least some debris flows had occurred in the past. All but two fans were $>25$ ha in area and the mean area was 56.8 ha. Because very few roads under the BRI have been constructed in the most challenging terrain, there is currently no baseline for comparison of the level of increase in sediment disasters associated with new or expanded roads in this region. Neverless, the road-related landslide data from Yunnan, China [33-35] suggest that major problems will occur unless improved planning and construction methods are employed. 


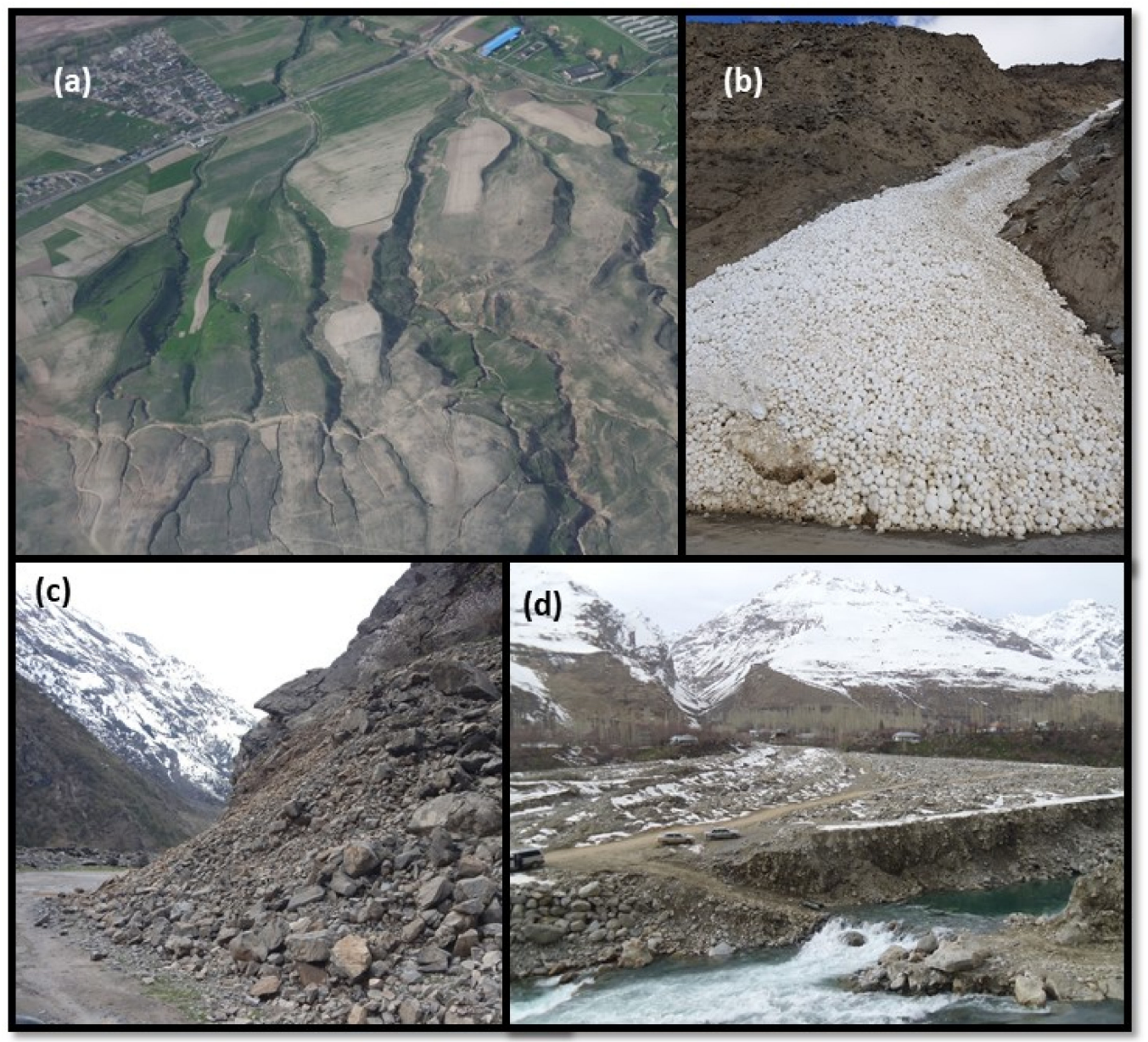

Figure 3. (a) Gully headcutting in silty soils due to runoff from roads and agricultural fields, Tajikistan; (b) Wet snow avalanche along the Pamir Highway; (c) Rockfall in the Pamir-Alay Range, Tajikistan; and (d) M41 road along the Gunt River in Tajikistan obliterated by a series of debris flows that also destroyed most of the village of Barsem; the debris fan was evident prior to this disaster.

Debris fans are particularly problematic for infrastructure, residences, and inhabitants, as these are prone to episodic avulsions [40]. Noteworthy is the largest fan along this M41 road section near Barsem, where a series of debris flows occurred during a warm period in July 2015 due to melting of permafrost near the terminal moraine of a glacier (Figure 3d). While most of the village was destroyed, the initial debris flow was small, and the inhabitants were able to evacuate before the larger debris flows emerged. Such precarious debris fans in Pamir valleys are commonly used for agriculture, settlements, and roads, as these are some of the only gentle topography in this mountainous region. Eight of the nine debris fans surveyed along this road segment were occupied by residences and farms. 


\section{Lessons Learned and Moving Forward}

To reduce environmental and human impacts of BRI road construction in mountainous Central Asia, governments must ensure that roads are properly located, designed, and maintained, with attention to reducing the connectivity of roads to streams. As noted, the lure of local economic benefits may not be realized, and more attention needs to concentrate on sustaining environmental attributes. Focusing on the entire road system, including the planning of spur roads, will reduce sediment transport to streams, flooding, and related downslope impacts on communities, agriculture, and aquatic habitat. The problems associated with valley bottom roads crossing large debris fans (Figure 3d) deserves special attention, where the probability of periodic avulsions needs to be assessed. All areas vulnerable to such natural hazards must be assessed by competent geoscience experts together with remote sensing monitoring to examine the broader issues and potential problematic connectivity of road and trail systems to streams.

Reducing foreign traffic into remote regions will protect residents against disease spread and social disruptions, particularly when residents minimally benefit from economic activities. Central Asia, particularly Tajikistan, Kyrgyzstan, and Afghanistan, is home to some of the poorest people; thus, these countries must focus on sustainable development solutions, not that pad the pockets of wealthier nations for short-term gains. Recognizing China's self-serving posture in its 'development projects', Central Asian governments should be proactive to ensure more sustainable planning and development of their road networks.

As a way of achieving more sustainable outcomes from the BRI for the poorest nations in Central Asia, governments and internal actors need to focus on a systematic approach that not only addresses short-term economic benefits, but also examines all externalities and potential impacts. Given that most discourses to date within these governments have concentrated on the former, the conceptual diagram in Figure 4 examines the concerns inherent in the latter. Entry points of government, development agency, and private actor interventions are somewhat implicit in the sectors outlined in light blue (e.g., Social \& Political, Environmental; Figure 4). Direct effects are most obvious, but the exogenous issues are also important, such as recognizing the history and biases inherent in practices linked to the development and mission of the BRI. It is imperative for these poor Central Asian nations to fully grasp these externalities and potential impacts to support sustainable livelihoods and environments. The second verse of Paul McCartney's ballad "The Long and Winding Road" embodies some of the potential issues at hand- "The wild and windy night, that the rain washed away, has left a pool of tears crying for the day". 


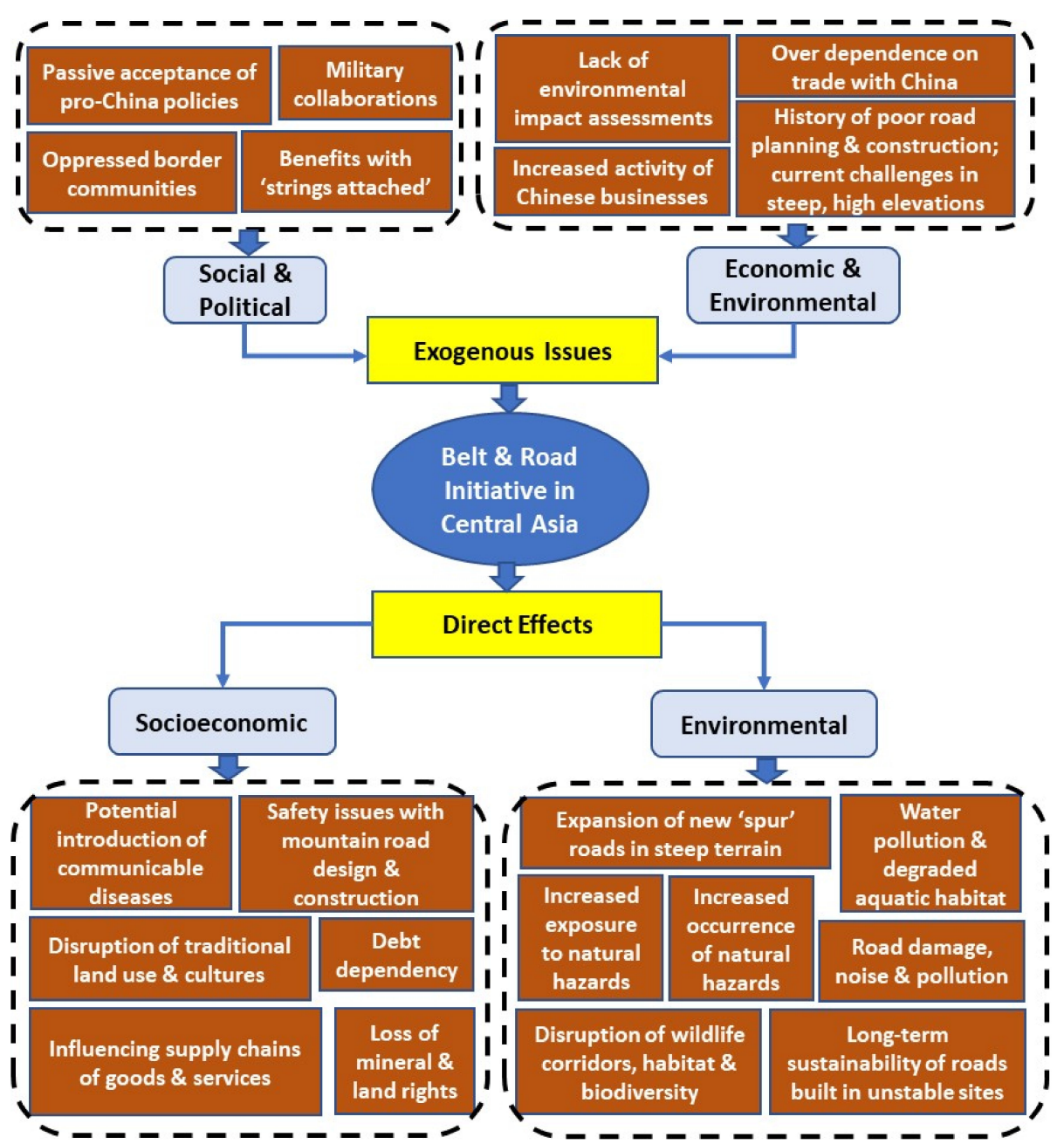

Figure 4. Conceptual representation of how exogenous issues as well as the direct effects of the Belt and Road Initiative may affect poorer countries in Central Asia. Light blue colored boxes indicate where sustainable interventions can be made by various sectors.

Funding: This study was supported by University of Central Asia and no external funding was received.

Acknowledgments: Graditude is expressed to Evgenii Shibkov for preparing the Silk Road map in Figure 1, as well as to the constructive comments by three external reviewers. All photographs in Figures 2 and 3 were taken by the author.

Conflicts of Interest: The author declares no conflict of interest.

\section{References}

1. Høisæter, T.L. Polities and nomads: The emergence of the Silk Road exchange in the Tarim Basin region during late prehistory (2000-400 BCE). Bull. Sch. Orient. Afr. Stud. 2017, 80, 339-363. [CrossRef]

2. Torr, G. The Silk Roads: A History of the Great Trading Routes between East and West; Arcturus Publishing: London, UK, 2018; p. 256.

3. Morelli, G.; Song, Y.; Mazzoni, C.J.; Eppinger, M.; Roumagnac, P.; Wagner, D.M.; Feldkamp, M.; Kusecek, B.; Vogler, A.J.; Li, Y.; et al. Phylogenetic diversity and historical patterns of pandemic spread of Yersinia pestis. Nat. Genet. 2011, 42, 1140-1143. [CrossRef] [PubMed]

4. Bos, K.I.; Schuenemann, V.J.; Golding, G.B.; Burbano, H.A.; Waglechner, N.; Coombes, B.K.; McPhee, J.B.; DeWitte, S.N.; Meyer, M.; Schmedes, S.; et al. A draft genome of Yersinia pestis from victims of the Black Death. Nature 2011, 478, 506-510. [CrossRef] [PubMed]

5. Kim, T.S. The Renaissance revisited: From a Silk Road perspective. Acta Serica 2018, 3, 11-25. 
6. Yang, D.; Cai, J.; Hull, V.; Wang, K.; Tsang, Y.P.; Liu, J. New road for telecoupling global prosperity and ecological sustainability. Ecosyst. Health Sustain. 2016, 2, e01242. [CrossRef]

7. Vakulchuk, R.; Overland, I. China's Belt and Road Initiative through the lens of Central Asia. In Regional Connection under the Belt and Road Initiative: The Prospects for Economic and Financial Cooperation; Cheung, F.M., Hong, Y.-Y., Eds.; Routledge: London, UK, 2019; Chapter 5; pp. 115-133.

8. Sternberg, T.; Ahearn, A.; McConnell, F. Central Asian 'characteristics' on China's New Silk Road: The role of landscape and the politics of infrastructure. Land 2017, 6, 55. [CrossRef]

9. Zimmerman, T. The New Silk Roads: China, the U.S., and the Future of Central Asia; Center on International Cooperation, New York University: New York, NY, USA, 2015; p. 21.

10. Rudelson, J.J. Oasis Identities; Columbia University Press: New York, NY, USA, 1997.

11. Greitens, S.C.; Lee, M.; Yazici, E. Counterterrorism and preventative repression. Int. Secur. 2020, 44, 9-47. [CrossRef]

12. Zeng, L. Conceptual analysis of China's Belt and Road Initiative: A road towards a regional community of common destiny. Chin. J. Int. Law 2016, 15, 517-541.

13. Tracy, E.F.; Shvarts, E.; Simonov, E.; Babenko, M. China's new Eurasian ambitions: The environmental risks of the Silk Road Economic Belt. Eurasian Geogr. Econ. 2017, 58, 56-88. [CrossRef]

14. Lechner, A.M.; Shun Chan, F.K.; Campos-Arceiz, A. Biodiversity conservation should be a core value of China's Belt and Road Initiative. Nat. Ecol. Evol. 2018, 2, 408-409. [CrossRef]

15. Teo, H.C.; Lechner, A.M.; Walton, G.W.; Shun Chan, F.K.; Cheshmehzangi, A.; Tan-Mullins, M.; Chan, H.K.; Sternberg, T.; Campos-Arceiz, A. Environmental impacts of infrastructure development under the Belt and Road Initiative. Environments 2019, 6, 72. [CrossRef]

16. Aung, T.S.; Fischer, T.B.; Shengji, L. Evaluating environmental impact assessment (EIA) in the countries along the belt and road initiatives: System effectiveness and the compatibility with the Chinese EIA. Environ. Impact Assess. Rev. 2020, 81, 106361. [CrossRef]

17. Sidle, R.C.; Benson, W.H.; Carriger, J.F.; Kamai, T. A broader perspective on ecosystem sustainability: Consequences for decision-making. Proc. Natl. Acad. Sci. USA 2013, 110, 9201-9208. [CrossRef] [PubMed]

18. International Crisis Group. Central Asia's Silk Road Rivalries; Crisis Group Europe and Central Asia Report N²45; International Crisis Group: Brussels, Belgium, 2017.

19. García-Herrero, A.; Xu, J. China's Belt and Road Initiative: Can Europe Expect Trade Gains? No. 2016/05; Bruegel Working Paper: Bruegel, Brussels. 2016. Available online: https://www.bruegel.org/wp-content/ uploads/2016/09/WP-05-2016.pdf (accessed on 5 November 2020).

20. Bossuyt, F. The EU's and China's development assistance towards Central Asia: Low versus contested impact. Eurasian Geogr. Econ. 2019, 59, 606-631. [CrossRef]

21. Cramb, R.A.; Pierce Colfer, C.J.; Dressler, W.; Laungaramsri, P.; Trang, Q.; Mulyoutami, E.; Peluso, N.L.; Wadley, R.L. Swidden transformation and rural livelihoods in Southeast Asia. Hum. Ecol. 2009, 37, 323-346. [CrossRef]

22. Xu, Z.; Niu, Y.; Liang, Y.; Li, Z.; Iftikhor, A. The integrated hydropower sustainability assessment in Tajikistan: A case study of Rogun Hydropower Plant. Adv. Civ. Eng. 2020, 8894072. [CrossRef]

23. Mahmudjon, H. Tajikistan's National Development Strategy 2030 and Chinese Contribution; Tracking Belt and Road Development in Tajikistan. Master's Thesis, School of Government, Peking University, Beijing, China, 2018.

24. Hafeez, M.; Chunhui, Y.; Strohmaier, D.; Ahmed, M.; Jie, L. Does finance affect environmental degradation: Evidence from One Belt and One Road Initiative region? Environ. Sci. Pollut. Res. 2018, 25, 9579-9592. [CrossRef]

25. Scobell, A.; Lin, B.; Shatz, H.J.; Johnson, M.; Hanauer, L.; Chase, M.S.; Cevallos, A.S.; Rasmussen, I.W.; Chan, A.; Strong, A.; et al. At the Dawn of Belt and Road: China in the Developing World; RAND Corp.: Santa Monica, CA, USA, 2018.

26. Mogilevskii, R. Kyrgyzstan and the Belt and Road Initiative; Working Paper 50; Institute of Public Policy and Administration, University of Central Asia: Bishkek, Kyrgyzstan, 2019.

27. Schmidt, M. Reconfigurations in Central Asia: Challenges, opportunities and risks of China's Belt and Road Initiative. In China and the New Silk Road; Pechlaner, H., Erchbamer, G., Thees, H., Gruber, M., Eds.; Springer: Berlin/Heidelberg, Germany, 2020; pp. 77-86. 
28. Liu, D.S.; Iverson, L.R.; Brown, S. Rates and patterns of deforestation in the Philippines: Application of geographic information system analysis. For. Ecol. Manag. 1993, 57, 1-16. [CrossRef]

29. Rohr, J.R.; Barrett, C.B.; Civitello, D.J.; Craft, M.E.; Delius, B.; DeLeo, G.A.; Hudson, P.J.; Jouanard, N.; Nguyen, K.H.; Ostfeld, R.S.; et al. Emerging human infectious diseases and the links to global food production. Nat. Sustain. 2019, 2, 445-456. [CrossRef]

30. Kassenova, N. China as an emerging donor in Tajikistan and Kyrgyzstan. Russie. Nei. Vis. 2009, 36, 11-13.

31. Lehr, A. Addressing Forced Labor in the Xinjiang Uyghur Autonomous Region; Center for Strategic \& International Studies Brief: Washington, DC, USA, 2020.

32. Sidle, R.C. and Ochiai, H. Landslides: Processes, Prediction, and Land Use; Water Resources Mono. 18; American Geophysical Union: Washington, DC, USA, 2006.

33. Sidle, R.C.; Ziegler, A.D. The dilemma of mountain roads. Nat. Geosci. 2012, 5, 437-438. [CrossRef]

34. Sidle, R.C.; Furuichi, T.; Kono, Y. Unprecedented rates of landslide and surface erosion along a newly constructed road in Yunnan, China. Nat. Hazards 2011, 57, 313-326. [CrossRef]

35. Sidle, R.C.; Ghestem, M.; Stokes, A. Epic landslide erosion from mountain roads in Yunnan, China-Challenges for sustainable development. Nat. Hazards Earth Syst. Sci. 2014, 14, 3093-3104. [CrossRef]

36. Haeberli, W. Construction, environmental problems and natural hazards in periglacial mountain belts. Permafr. Periglac. Process. 1992, 3, 111-124. [CrossRef]

37. Jones, J.A.; Swanson, F.J.; Wemple, B.C.; Snyder, K.U. Effects of roads on hydrology, geomorphology, and disturbance patches in stream networks. Conserv. Biol. 2000, 14, 76-85. [CrossRef]

38. Sidle, R.C.; Sasaki, S.; Otsuki, M.; Noguchi, S.; Abdul Rahim, N. Sediment pathways in a tropical forest: Effects of logging roads and skid trails. Hydrol. Process. 2004, 18, 703-720. [CrossRef]

39. McClung, D.M. Avalanche character and fatalities in the high mountains of Asia. Ann. Glaciol. 2016, 57, 114-118. [CrossRef]

40. De Haas, T.; Densmore, A.L.; Stoffel, M.; Suwa, H.; Imaizumi, F.; Ballesteros-Cánovas, J.A.; Wasklewicz, T. Alvusions and the spatio-temporal evolution of debris-flow fans. Earth-Sci. Rev. 2018, 177, 53-75. [CrossRef]

Publisher's Note: MDPI stays neutral with regard to jurisdictional claims in published maps and institutional affiliations.

(C) 2020 by the author. Licensee MDPI, Basel, Switzerland. This article is an open access article distributed under the terms and conditions of the Creative Commons Attribution (CC BY) license (http://creativecommons.org/licenses/by/4.0/). 